\title{
Active methane venting observed at giant pockmarks along the U.S. mid-Atlantic shelf break
}

Kori R. Newman*a,b ${ }^{\text {, }}$ Marie-Helene Cormier ${ }^{\mathrm{a}, 1}$, Jeffrey K. Weissel ${ }^{\mathrm{a}}$, Neal W. Driscoll ${ }^{\mathrm{c}}$, Miriam Kastner ${ }^{\mathrm{c}}$, Evan A. Solomon ${ }^{\mathrm{c}}$, Gretchen Robertson ${ }^{\mathrm{c}}$, Jenna C. Hill ${ }^{\mathrm{c}, 2}$, Hanumant Singh $^{\mathrm{d}}$, Richard Camilli ${ }^{\mathrm{d}}$ and Ryan Eustice ${ }^{\mathrm{d}, 3}$

${ }^{a}$ Lamont-Doherty Earth Observatory of Columbia University, Palisades, NY 10964, ${ }^{b}$ Department of Earth and Environmental Sciences, Columbia University, New York, NY 10027

${ }^{\mathrm{c}}$ Scripps Institution of Oceanography, La Jolla, CA 92093

${ }^{\mathrm{d}}$ Woods Hole Oceanographic Institution, Woods Hole, MA 02543

${ }^{1}$ Present address: Department of Geological Sciences, University of Missouri, Columbia, MO 65211

${ }^{2}$ Present address: Center for Marine and Wetland Studies, Coastal Carolina University, Conway, SC 29526

${ }^{3}$ Present address: Department of Naval Architecture and Marine Engineering, University of Michigan, Ann Arbor, MI 48109

*Corresponding author; Lamont-Doherty Earth Observatory, 304B Oceanography, P.O. Box 1000, Palisades, NY 10964, E-mail: knewman@1deo.columbia.edu, ph: +1 (845) 365-8461, fax: +1 (845) 365-8156

\begin{abstract}
Detailed near-bottom investigation of a series of giant, kilometer scale, elongate pockmarks along the edge of the mid-Atlantic continental shelf confirms that methane is actively venting at the site. Dissolved methane concentrations, which were measured with a commercially available methane sensor (METS) designed by Franatech GmbH mounted on an autonomous underwater vehicle (AUV), are as high as $100 \mathrm{nM}$. These values are well above expected background levels (1-4 nM) for the open ocean.

Sediment pore water geochemistry gives further evidence of methane advection through the seafloor. Isotopically light carbon in the dissolved methane samples indicates a primarily biogenic source. The spatial distribution of the near-bottom methane anomalies (concentrations above open ocean background), combined with water column salinity and
\end{abstract}


temperature vertical profiles, indicate that methane-rich water is not present across the entire width of the pockmarks, but is laterally restricted to their edges. We suggest that venting is primarily along the top of the pockmark walls with some advection and dispersion due to local currents. The highest methane concentrations observed with the METS sensor occur at a small, circular pockmark at the southern end of the study area. This observation is compatible with a scenario where the larger, elongate pockmarks evolve through coalescing smaller pockmarks.

Keywords: pockmarks; seafloor venting; methane; AUV 


\section{Introduction}

It is estimated that 6.6-19.5 $\mathrm{Tg}$ of methane per year are released from the marine environment into the atmosphere, making natural gas seeps an important part of the global methane budget [Judd et al., 2002]. Methane seeps can occur in most marine environments [Judd, 2003] with seep characteristics ranging from diffuse seafloor venting to more focused escape [Lonke et al., 2004]. In addition to the environmental significance, gas in marine sediments might hold possible geohazard and resource significance [e.g. Sills \& Wheeler, 1992].

Pockmarks associated with the venting of gas-rich fluids have become widely observed seafloor features since their first discovery by King and McLean [1970] offshore Nova Scotia [Hovland and Judd, 1988]. The cross-sectional shape of these features varies from U-shaped and V-shaped seafloor depressions to truncated cones with steep, low angled or asymmetric walls. Some are circular in plan view while others are elongate [Dimitrov and Woodside, 2002; Hovland et al., 2002]. While most agree that pockmarks are the result of focused fluid flow [Hovland et al., 2002], the exact nature of venting remains poorly understood [Paull et al., 2002]. Kelley et al. [1994] suggest two models for pockmark formation: 1) organic matter deposited above an erosional surface decomposes, releasing gas that excavates the pockmark; once the excavation extends to the erosional surface, the pockmark spreads out laterally along the erosional surface, and 2) a catastrophic event such as an earthquake or tsunami reduces the confining pressure in the area, allowing gas and fluids to suddenly escape. The first model can explain why Ushaped, V-shaped and flat-floored pockmarks are observed, and the latter model why 
pockmark formation and increased methane venting have been documented to occur in response to earthquakes [Hovland et al., 2002; Christodoulou et al., 2003].

Using newly released bathymetry from NOAA, several large, elongate, en echelon pockmarks were discovered at the edge of the Virginia/North Carolina continental shelf (Fig. 1) by Driscoll et al. [2000]. While the usual scale of pockmarks ranges from a few meters to $\sim 300 \mathrm{~m}$ in diameter and up to $25 \mathrm{~m}$ in relief [Christodoulou et al, 2003, Çifçi et al., 2003, Dimitrov et al., 2002], these shelf-edge features are several kilometers long, up to a kilometer across and $50 \mathrm{~m}$ in relief. Until these pockmarks were discovered, pockmarks exceeding $350 \mathrm{~m}$ in diameter and $35 \mathrm{~m}$ in relief were classified as "giant" [Kelley et al., 1994]. These shelf-edge features were initially interpreted as small-offset normal faults diagnostic of some incipient slope failure [Driscoll et al, 2000]. However, further investigation in 2000 using sidescan sonar and high-resolution subbottom profiling (chirp) showed that these features are produced by gas seepage because abundant gas is imaged in the sedimentary section housing the giant pockmarks (Fig. 2) [Hill et al, 2004]. Those authors proposed a mechanism for formation of the pockmarks in which methane migrates upslope beneath an impermeable shelf edge delta, creating an overpressure that, combined with downslope creep, eventually leads to failure during which gas is expelled. Hill et al. [2004] thus describe them as "gas blowouts." This scenario implies a pockmark age younger than the last glacial maximum when the shelf edge delta presumably formed.

Based on the existing shipboard data, it is not clear whether gas continues to vent through the expulsion features since their development, and whether the gas is thermogenic or biogenic in origin. For example, pockmark fields recently mapped in 
Belfast Bay, ME and off-shore Big Sur, CA show no sign of active venting [Paul et al., 2002; Ussler et al., 2003]. The grid of chirp profiles collected during the 2000 study clearly document gas within the shallow sediment at the walls of the pockmarks (Fig. 2) [Hill et al., 2004]. However, unlike what has been reported in some other regions [e.g. Judd and Hovland, 2007; Christodoulou et al., 2003], gas bubble plumes have not been acoustically imaged in the water column. No sampling was performed during the 2000 survey that would verify if gas venting is presently occurring.

In July 2004, we carried out a detailed survey of the giant, shelf-edge pockmarks with the R/V Cape Hatteras to determine if methane is actively venting at these sites, and if so, to constrain the source of gas and its fate in the water column. We made in situ, near bottom measurements of dissolved methane concentration in the pockmarks and surrounding areas using two emerging technologies, an Autonomous Underwater Vehicle (AUV) and a vehicle-mounted, underway METS methane sensor. We collected cores, pore fluids and water column samples for geochemical analysis to document the presence and nature of gas discharge.

\section{Data Acquisition}

\subsection{Multibeam Bathymetric Survey}

We acquired new high resolution multibeam swath bathymetry data to better define and locate sediment and water column sampling sites, as well as provide improved navigation for the AUV missions (Figs. $1 \&$ 7). The area was previously mapped in 1990 by NOAA (www.ngdc.noaa.gov/mgg/bathymetry/hydro.html) using a $36 \mathrm{kHz}$ Hydrochart II multibeam bathymetric system. Precise navigation of the AUV required bathymetric 
maps of greater accuracy than the NOAA data, so a pole-mounted SeaBeam/ELAC multibeam system was leased to produce a new, higher resolution map of the pockmarks. This multibeam system operates at $180 \mathrm{kHz}$ with a swath width of $153^{\circ}$ and 126 beams per ping. Velocity profiles used for processing the multibeam data were calculated from daily casts of expendable bathythermographs (XBTs). Ship tracks, aligned parallel to the shelf edge, were spaced $150 \mathrm{~m}$ apart to ensure $\sim 100 \%$ swath overlap in constructing the final bathymetric map (Fig. 1).

\subsection{SeaBED AUV Missions}

AUVs are now sophisticated enough that they can perform accurately georeferenced, detailed, near-bottom surveys that were previously considered too expensive using remotely operated vehicles (ROVs) or manned submersibles [Whitcomb et al., 2000; Singh et al., 2004a]. The AUV SeaBED (Fig. 3) was designed at the Woods Hole Oceanographic Institution for easy transport to remote locations as well as to be deployable from small ships of opportunity, both of which reduce operational costs and ease survey logistics [Singh et al., 2004a\&b].

The SeaBED AUV completed 16 successful dives (out of 18 deployments) across the pockmarks during which the vehicle followed a pre-programmed track at a speed of approximately $0.5 \mathrm{~m} / \mathrm{s}$ over ground while maintaining an altitude of $3 \mathrm{~m} \pm 0.1 \mathrm{~m}$ above the seafloor. The AUV made continuous, in situ measurements of the water properties in the pockmarks. A METS methane sensor, manufactured by Franatech GmbH, Germany, to measure in situ dissolved methane concentration, and a Seabird Fastcat CTD were mounted on the AUV. Water was simultaneously pumped into both instruments so that 
each was analyzing the same water sample. Microbathymetric data and color photographs of the seafloor were also acquired continuously along track. Water property measurements were made approximately every second and photographs taken every 3 seconds. The interval between photographs was selected to ensure some overlap between frames so that continuous photomosaics could be constructed.

The shipboard Acoustic Doppler Current Profiler (ADCP) was used to determine the overall trend and strength of currents in the area, as needed for planning the AUV dives. Underway AUV navigation was based on compass readings on the vehicle and a vehicle mounted ADCP. Track navigation was adjusted after the completion of each dive using ship-to-vehicle sonar ranging in conjunction with shipboard differential GPS. Further re-navigation, comparing AUV measured seafloor depth with the shipboard, GPS-navigated multibeam bathymetry, was needed because the vehicle's bottom-track velocity measurements included a component of the strong SSW shelf-edge current [Eustice et al., 2005]. This current, which is clearly expressed in the shipboard ADCP data (Fig. 4), flows southward along the US east coast shelf edge [Bumpus, 1973].

\subsection{Water and Sediment Sampling Program}

Hydrocasts, located on Fig. 1, were deployed to collect water column samples. The Conductivity, Temperature and Depth (CTD) profile from each descent of the hydrocast were used to identify optimal water sample collection depths during ascent. Collected water samples were immediately stored in nitrogen-purged $125 \mathrm{~mL}$ serum bottles, poisoned with mercuric chloride to halt any methane production and oxidation, and were later analyzed for dissolved hydrocarbon concentrations and methane $\delta^{13} \mathrm{C}$. 
Methane concentrations were measured with a gas chromatograph equipped with a flame ionization detector (GC 8A, Shimadzu Corp.) and the methane $\delta^{13} \mathrm{C}$ isotopic analyses were performed on a Finnigan MAT252 mass spectrometer with a GC1 interface at the University of Hawaii following the technique of Popp et al. [1995]. The average percent precision of the methane concentration and methane $\delta^{13} \mathrm{C}$ analyses are $<3 \%$ and $\pm 0.6 \%$, respectively. Other water aliquots were analyzed aboard the ship for salinity and alkalinity and the rest preserved for shore-based analyses.

Sediment cores were collected throughout the survey area (Fig. 1). Approximately half of the cores were saved for sedimentology and stratigraphy. Selected cores were subsampled under anaerobic conditions and the pore fluid was extracted onboard using titanium squeezers. All pore fluids were passed through $0.45 \mu \mathrm{m}$ Gelman polysulfate filters to remove the remaining suspended silt and were immediately subsampled under anaerobic conditions for various shore-based analyses. Aliquots for major and minor element analyses were stored in acid-cleaned polypropylene centrifuge tubes and acidified with Optima nitric acid. Dissolved inorganic carbon (DIC) samples were poisoned with a saturated mercuric chloride solution and stored in vacutainers. Sample aliquots for sulfate analyses were added to acid-cleaned polypropylene centrifuge tubes containing a $50 \% \mathrm{CdNO}_{3}$ solution to precipitate out the sulfide, thus leaving only sulfate in solution. Alkalinity and $\mathrm{pH}$ were measured immediately onboard by Gran titration, and chloride concentrations were determined by titration with $\mathrm{AgNO}_{3}$. Sulfate concentrations were determined via ion chromatography (precision $<0.6 \%$ ), and DIC $\delta^{13} \mathrm{C}$ was measured on a ThermoFinnigan Delta XP Plus stable isotope ratio mass spectrometer, with an average percent precision $<1.8 \%$. Sediment sub-samples for pore 
fluid methane concentration and $\delta^{13} \mathrm{C}$ isotope ratios were immediately taken after core recovery, stored in nitrogen-purged serum bottles, and preserved with a saturated mercuric chloride solution. Methane concentrations and carbon isotopic ratios were determined using the same techniques as described for the water column samples.

\section{Results}

\subsection{New Multibeam Bathymetric Map}

The new bathymetric map (Figs. $1 \& 7$ ) is of higher resolution than the existing NOAA bathymetry. The higher sonar frequency and the dense across track spatial sampling allowed us to produce a new map based on a grid spacing of $8 \mathrm{~m}$. Although the giant pockmarks are well imaged with the NOAA 3" grid, the higher resolution map yields more accurate information in steeper terrain. In particular, it highlights the striking linearity of the landward pockmark walls (Figs. $1 \& 7$ ).

The amount of material excavated from the pockmarks can be estimated from the new high resolution bathymetric map. The average volume of the pockmarks is on the order of $10^{7} \mathrm{~m}^{3}$ with the smallest pockmark having a volume of $3 \cdot 10^{6} \mathrm{~m}^{3}$ and the largest having a volume of $4 \cdot 10^{7} \mathrm{~m}^{3}$. The total volume of the pockmarks within our study area is $\sim 10^{8} \mathrm{~m}^{3}$. Assuming a typical porosity of $60-70 \%$, this indicates that about $3-4 \cdot 10^{7} \mathrm{~m}^{3}$ of sediment have been removed from the pockmarks since their formation.

\subsection{AUV Along Track Data}

The METS sensor, mounted on the SeaBED AUV, routinely measured dissolved methane concentration. The along track data exhibit a systematic negative correlation of 
dissolved methane concentration with temperature and salinity (Fig. 5). We found, however, that the METS sensor response is characterized by a significant time lag to changes in dissolved methane concentration. At places where sharp gradients in salinity and temperature occur, indicating a change in water mass, dissolved methane concentrations grow or decay over a $\sim 15$ minute period and plateau until a similar sharp salinity and temperature gradient is encountered. This pattern suggests that the methane concentration values are affected by instrument performance and we have devised a method to correct for the instrument response (see Appendix). After correction, the resulting dissolved methane concentration data mirror that of salinity and temperature, increasing when salinity and temperature decrease (Figs. 5 \& 6). Additionally, we observe a correlation between methane concentrations and bathymetry where methane anomalies are all located at depths shallower than $130 \mathrm{~m}$, which corresponds to the upper walls of the pockmarks and the adjacent shelf edge (Figs. $6 \& 7$ ).

Dissolved methane concentrations also vary temporally. The data from the first three AUV dives show generally high methane concentrations throughout the deployments. Two storms occurred during the early part of the cruise, before dive 4 and before dive 9. Immediately after the second storm, methane concentrations dropped to very low levels for the next three dives. During the remainder of the AUV dives the average background methane concentration increased slowly with time after the storms. This is demonstrated by crossover errors in relative methane concentration between the data collected recently after the storm and those collected near the end of the survey (Fig. 7b). 
Inspection of the 44,000 photos collected by the AUV do not show the faunal or bacterial communities typical of cold seeps [e.g. Hovland and Judd, 1988; Sibuet and Olu, 1998; Judd and Hovland, 2007]. Instead, seafloor sediment texture varies from mud to gravel, and the commonly observed fauna include fish (such as skate and chain dogfish), starfish and anemones. Hence, if cold seeps are present within the study area, their lateral extent must be less than the average spacing of the AUV tracks (50 meters to a few hundred meters).

\subsection{Spatial Distribution of Methane Anomalies}

Instead of interpreting the temporally varying absolute methane concentrations, we grouped methane anomalies into three categories: background concentration, high concentration and intermediate concentration (Fig. 6). Background concentration is defined as the average low concentration for each dive (usually $<10 \mathrm{nM}$ ). High concentration areas display distinct methane anomalies well above background ( $>50 \mathrm{nM})$ and are characterized by a steep along-track gradient at either end. Areas identified as intermediate concentration have dissolved methane concentrations that are higher than background, but are either lower than areas identified as high concentration, are slowly increasing or decreasing along-track, or are fluctuating.

Figure 7 displays the spatial distribution of methane anomalies according to the above three categories. It includes 13 SeaBED dives that we evaluated to be the most consistent and reliable of the successful deployments on the basis of cross-over errors at track intersections. The northern part of the survey area (Fig. 7a) shows high methane on the landward walls of the pockmarks and on the shelf landward of the pockmarks with no 
methane over the floors of the pockmarks. The southern pockmarks (Fig. 7c) show a similar pattern. However, the small, circular pockmark in the south appears to have little or no methane to the north and west, but shows a streak of elevated methane concentration extending from its southern wall toward the southeast. The middle section of the survey (Fig. 7b) is the most complex and the most densely sampled. High methane is observed along the western walls of the pockmarks and continues along the shelf to the west. Elevated methane is observed at the bathymetric highs along the eastern edges of the pockmarks. All dives, except dive 4, show little to no methane venting at the floors of the pockmarks. Dive 4, one of the earliest dives, is anomalous and displays high methane throughout most of the deployment, even along the floor of the pockmark. Low methane concentration is only observed on dive 4 outside of the pockmark, down the continental slope from the shelf break at depths greater than $160 \mathrm{~m}$ (Fig. 7b). Dives 5 and 8 were not plotted because the corrected methane concentrations appear too internally inconsistent within the deployments: methane concentrations change only when the vehicle begins to travel down slope suggesting that other factors, such as the vehicle's response to the changing bathymetry may also affect measurements. Dive 1 displays higher dissolved methane concentrations compared to all the other dives and was omitted due to inability to separate the data into the three previously mentioned classifications and because the dissolved methane concentration, salinity and temperature correlation is less robust. This pattern might be due to initial calibration issues. 


\subsection{Dissolved Hydrocarbons in Water Column Samples}

We measured dissolved methane concentrations as high as $40 \mathrm{nM}$ in water column samples collected with the hydrocasts (supplementary Table 1). The measured concentrations are significantly higher than those in average seawater (1-4 $\mathrm{nM}$ [Holmes et al, 2000; Sansone et al., 2001; Reeburgh, 2007]). In all the hydrocast profiles, low methane occurs near the floors of the pockmarks and higher concentrations occur at depths corresponding to the top of the pockmark walls (100-130 m), consistent with the near-bottom measurements made from the AUV. In most profiles, the correlation between salinity, temperature and methane concentration, observed for near-bottom AUV measurements (Fig. 6), breaks down with altitude above the seafloor (Fig. 8). In addition to the elevated methane concentrations, trace amounts of higher molecular weight hydrocarbons, mainly ethane and propane, were measured in the water column. Dissolved ethane, propane and butane concentrations are usually negligible, but in some samples ethane and propane concentrations are more prominent. Isotopic analysis of the

dissolved methane in the hydrocast samples shows that the methane $\delta^{13} \mathrm{C}$ values range from -65 to $-45 \%$, with most measurements less than $-60 \%$ (supplementary Table 1 ).

\subsection{Pore Fluid Geochemistry}

Depth profiles of DIC $\delta^{13} \mathrm{C}$ values and sulfate concentration in sediment pore fluids yield information about the nature of the microbiological reactions, on organic matter diagenesis, methane flux, and anaerobic methane oxidation (AMO). Sulfate profiles have been obtained for pore fluids squeezed from piston cores 10P, 23P, 25P, 30P, 31P and 34P and DIC $\delta^{13} \mathrm{C}$ profiles from 10P, 23P and 25P (Fig. 9; Table 1; 
Supplementary Table 2). Sulfate concentration decreases with depth below the seafloor, reaching zero concentration at depths as shallow as $50-65 \mathrm{~cm}$ below the seafloor in core $30 \mathrm{P}$ and $34 \mathrm{P}$. DIC $\delta^{13} \mathrm{C}$ also decreases with depth, reaching a minimum of $-34.4 \%$ at $115-138 \mathrm{~cm}$ below the seafloor in core 10P (Table 1). The shallowness of the sulfate reduction zone and isotopically light DIC $\delta^{13} \mathrm{C}$ suggest active methane advection and AMO at the pockmarks [Browski et al., 1999].

\section{Discussion}

\subsection{Methane Venting at the Pockmarks}

The observed methane anomaly concentrations of 50-150 nM and $\sim 30 \mathrm{nM}$ observed in the METS sensor data and in the hydrocast samples, respectively, are significantly higher than average seawater dissolved methane concentrations (1-4 nM), confirming that methane is actively venting in the pockmarks. While these values are lower than the 200-1500 $\mathrm{nM}$ concentration measured at some other pockmarks [e.g. Bohrmann et al, 2002; Christodoulou et al., 2003], they are significantly higher than 1-3 nM concentrations observed in pockmarks with no evidence of venting [Paull et al., 2002].

The shallowness of the sulfate methane interface (SMI) and the isotopic signature of the DIC also support methane advection and AMO (Table 1). Two processes contribute to sulfate reduction [Claypool and Kaplan, 1974; Borowski et al., 1999]: Organic Matter Oxidation (OMO)

$$
2\left(\mathrm{CH}_{2} \mathrm{O}\right)+\mathrm{SO}_{4}{ }^{2-} \rightarrow 2 \mathrm{HCO}_{3}{ }^{-}+\mathrm{H}_{2} \mathrm{~S},
$$


and Anaerobic Methane Oxidation (AMO)

$$
\mathrm{CH}_{4}+\mathrm{SO}_{4}{ }^{2-} \rightarrow \mathrm{HCO}_{3}^{-}+\mathrm{HS}^{-}+\mathrm{H}_{2} \mathrm{O} \text {. }
$$

The DIC is expressed in the bicarbonate ion $\left(\mathrm{HCO}_{3}^{-}\right)$in these reactions. OMO, which is the more common of the two reactions, occurs in all sulfate-reducing environments when organic matter is present. In the presence of only OMO, the minimum $\delta^{13} \mathrm{C}$ of the resulting DIC is equal to that of the organic carbon involved in the reaction. Organic carbon has a typical $\delta^{13} \mathrm{C}$ range of $-20 \%$ to $-22 \%$ for marine carbon and $-26 \%$ to $-32 \%$ o for terrigenous carbon [Hedges, 1992]. However, east coast U.S. rivers deliver particulate organic carbon that can be isotopically lighter $(-33.7 \%$ for the Parker River [Raymond and Bauer, 2001]). Conversely, DIC $\delta^{13} \mathrm{C}$ values resulting from AMO can be less than that of OMO because methane is isotopically lighter. We measured methane $\delta^{13} \mathrm{C}$ less than $-60 \%$ in our water column samples. The minimum $\delta^{13} \mathrm{C}$ of the DIC in the pore fluids ranges from $-30.9 \%$ to $-34.4 \%$ (Table 1 ). Given that the isotopic composition of the pore fluid DIC represents a mixture of all end member sources of carbon involved in sulfate reduction [e.g. Blair et al, 2004], the minimum value of the DIC $\delta^{13} \mathrm{C}$ found in the pore fluids suggests that AMO is the dominant sulfate reducing process in the shallow sedimentary section. This is consistent with the shallow depth to the SMI observed in the core pore fluids (Table 1). The pore fluid geochemistry results strongly suggest that methane is actively being advected toward the seafloor.

In the pockmarks, elevated methane concentrations coincide with T-S anomalies, indicating that the vented fluids are cooler and less saline than the background water. A possible source of this anomalous water is water emplaced as groundwater during the last glacial maximum when sea level was $\sim 130 \mathrm{~m}$ below current sea level, leaving the shelf 
edge exposed. Groundwater would have been present beneath the shelf edge and would be fresh by nature and cold because of the cooler ambient temperature. Accordingly, ODP sites 1071 and 1072 on the New Jersey margin sampled interstitial water with salinities as low as 25 [Austin et al., 1998], showing that fresher water is present in the subsurface.

\subsection{Methane Source}

The $\delta^{13} \mathrm{C}$ of the methane is sufficiently light to indicate a primarily biogenic source for the vented methane. Methane $\delta^{13} \mathrm{C}$ lower than $-60 \%$ is generally attributed to biogenic methane, whereas methane $\delta^{13} \mathrm{C}$ heavier than $-45 \%$ is considered thermogenic in origin [Whiticar et al., 1986; Ussler et al., 2003]. Since most of the water column methane $\delta^{13} \mathrm{C}$ is less than $-60 \%$, the vented methane has a primarily biogenic signature.

Isotopically light methane can also be produced abiogenically under serpentinizing conditions through reactions catalyzed by metallic minerals found in igneous rocks [Horita and Berndt, 1999]. However, in our region $10 \mathrm{~km}$ of sediment overlie the basement within the study area [Holbrook et al., 1994] and faults are not observed that would allow fluids to migrate through the sediment carapace. Thus, it seems unlikely that serpentinization processes contribute to the vented methane we observe.

\subsection{Diffuse vs. focused venting}

The spatial distribution of the elevated methane concentrations (Fig. 7) and the CTD profiles (Fig. 8) show that methane rich fluids are not present along the floors of the 
pockmarks. This is consistent with previous observations based on high-resolution (chirp) seismic profiling [Hill et al., 2004], where gas-charged sediments are seismically imaged along the walls of the pockmarks, but in most cases gas is not seismically imaged beneath the floors of the pockmarks (e.g. Fig. 2).

The pattern of methane venting illustrated by the AUV data itself is not sufficient to determine the overall venting pattern in the area. Since the AUV maintained an altitude of $3 \mathrm{~m}$ above seafloor during the dives, its depth below the sea surface constantly changed. Thus, the observed variations in methane concentration might be due to horizontal stratification, such as those observed by Berner et al. [2003], rather than to focused venting of methane-rich fluids. To determine if a horizontally extensive methane-rich layer exists, the near-systematic correlation between salinity, temperature and dissolved methane concentration was exploited by examining CTD profiles acquired by the AUV during its descent to and ascent from the seafloor. The observed near seafloor relationship between dissolved methane concentration, salinity and temperature tends to break down in the water column (Fig. 8), likely due to mixing occurring in a water column with existing vertical structure. Vertical profiling may still be useful to evaluate the horizontal extent of a well defined methane-rich layer. Near the seafloor, methane anomalies occur in areas where the salinity and temperature are lower than the surrounding water, indicating that the vented methane-rich fluid is less saline and cooler than the bottom water. These observed salinity and temperature gradients are not due to the interfingering of shelf and slope water resulting from the summer weakening of the shelf/slope front as described by Flagg, et al. [1994], Burrage and Garvine [1982] and Gordon and Aikman [1981]. Structure related to that feature is visible farther up in the 
water column, at water depths shallower than $80 \mathrm{~m}$. The overall trend in the $100-150 \mathrm{~m}$ water depths of the study area is that both temperature and salinity increase significantly with depth (Figs. $8 \& 10$ ). Therefore, as altitude increases, the affect on temperature and salinity due to mixing will become less pronounced as the physical characteristics of the water approach those of the vented fluids. This water column structure enables us to locate the base of the methane-rich layer by a sharp gradient in temperature and salinity, but above that step-like variation in physical properties, the previously observed correlation between dissolved methane concentration, salinity and temperature will become less robust and the top of the methane-rich layer may not be sharply defined in the temperature and salinity data.

We observe evidence of a methane-rich layer in most of the CTD profiles generated during the AUV descents and ascents that extend deeper than $100 \mathrm{~m}$ and are sited near the landward (west) walls of the pockmarks. However, profiles collected during the ascents of dives 9 and 18 (Fig. 8) do not show steps in salinity and temperature, suggesting that the observed methane-rich water mass is not laterally continuous. These two profiles are far enough away from the pockmark walls that advection due to tidal forcing (Fig. 4) would not have carried the methane-rich fluids to the profile location.

Based on these observations, we hypothesize that the pattern in the spatial distribution of the methane anomaly mostly reflects an area of venting along the walls of the pockmarks with some transport by local currents contributing to the observed distribution of the methane (Fig. 10). We have considered other venting scenarios, including localized venting at specific sites, either along the pockmark walls or through 
the floor of the pockmarks, or a methane-rich water mass transported from elsewhere. However, these are unlikely because they require the presence of a laterally extensive methane-rich water layer that is not supported by the data.

\subsection{Temporal Variations in Methane Venting}

During this survey we observed temporal variations in methane concentration with background methane concentrations near the seafloor dropping to insignificant levels after two storms and then gradually increasing. Examination of XBT and CTD profiles collected throughout the cruise show that the structure of the water column also changed in response to the two storms. Thus, it seems likely that the storms either shifted the water masses in the area, clearing the methane-rich water that had accumulated in the pockmarks, or induced water column mixing so that methane concentrations were greatly reduced near the seafloor. In effect, these storms seem to have "reset the system," and provided an unexpected opportunity to track the build up of the methane anomalies.

Changes in seepage rates that coincide with tidal variations are commonly observed [e.g. Mikolaj and Ampaya, 1973; Orange et al, 1997; Boles et al., 2001; Torres et al., 2002; Forrest et al., 2005]. Christodoulou et al. [2003] observe both seasonal changes in methane concentration after sampling water above pockmarks on a monthly basis as well as increased methane concentrations following an earthquake. Boles et al. [2001] document tidal forcing resulting in 4-7\% variations about the mean in methane concentrations measured in situ by tent-shaped traps placed on the seafloor. Within the study area, the tidal effect at the seafloor is apparent in the shifting current directions (Fig. 4). However, because our measurements were not taken in a stationary position 
over a tidal cycle, the magnitude of the tidal forcing on these pockmarks cannot be quantified. Nonetheless, based on reported variations in methane concentration in other nearshore settings and cross-over errors between subsequent AUV dives, we estimate that tidal forcing results in less than a $20 \%$ variation in methane concentration about the mean local value.

\subsection{Evolution of Elongate Pockmarks}

Most of the pockmarks in our survey area are kilometer-scale, elongate features, but a smaller, circular pockmark is present at the southernmost part of the survey area (Figs. $1 \& 7$ c). This pockmark is $\sim 300 \mathrm{~m}$ in diameter and has slightly less relief $(<40 \mathrm{~m})$ than the other pockmarks in the area. The largest methane anomaly was recorded along the southwestern wall of this pockmark during AUV dive 12, possibly indicting that venting is more vigorous in this pockmark. Pockmark fields with no evidence of gas or fluid venting have been identified [e.g. Paull et al., 2002]. Judd and Hovland [2007] suggest that features like these might be relict, indicating earlier gas or fluid venting. Ivanov et al. [2007] similarly conclude that the remains of chemosynthetic communities found in pockmarks on the Vøring Plateau off western Norway give evidence of previous fluid venting that has since ceased. We further hypothesize that as the pockmarks age and the reservoir of vent material becomes depleted, venting rates might be reduced. According to this scenario, the southernmost pockmark might be the youngest. Our data are spatially limited, so it is possible that high methane concentrations exist in other parts of the survey area and were not sampled. However, if the smallest pockmarks are indeed 
the youngest, it would support Kelley et al.'s [1994] model of pockmark formation in which the pockmarks are gradually enlarged due to gas or fluid escape.

Hill et al. [2004] attribute the elongate nature of the pockmarks to stress changes resulting from downslope creep within the shelf edge delta. Çifçi et al. [2003] hypothesized that elongate pockmarks on the Turkish shelf of the Black Sea formed by the merging of smaller pockmarks. There, the round pockmarks were $1 / 4-1 / 2$ the size of the larger, elongate pockmarks. These two mechanisms are not mutually exclusive and their combined effect might be responsible for the formation of the pockmarks in our study area. The smaller pockmarks could be younger and thus have not yet had sufficient time to grow and merge with adjacent pockmarks. The irregularly shaped pockmark where cores 10P, 23P and 25P were collected (Fig. 7b) might get its shape from the coalescing of three or more smaller pockmarks (the thin northward extension and the easternmost section of the pockmark could each have been separate features before joining with what is now the central portion of the pockmark). Downslope creep also likely contributes to the shape of the features by influencing where the pockmarks form and by causing them to preferentially align and spread parallel to the shelf break. The western walls of the pockmarks are very linear, systematically oriented parallel to the continental slope, and are arranged in an en-echelon, left-stepping pattern, all of which suggest their formation is partially controlled by local stress at the shelf edge. Hence, the tensional regime, induced by creep processes in the deltaic sediments draped over the shelf edge, controls the locations of the pockmarks, likely resulting in linear array of circular pockmarks that eventually coalesce into en echelon, elongate features. 


\section{Conclusions}

Near seafloor dissolved methane concentration measurements from the SeaBED AUV, combined with CTD profiles, document the distribution of active venting in the pockmarks along the U.S. mid-Atlantic shelf edge. Methane venting is concentrated along the upper parts of the pockmark walls and adjacent shelf area and is not occurring through the floors of the pockmarks. A correlation is observed, both in the AUV and the lower sections of hydrocast data, between increased methane concentration and decreased salinity and temperature. This correlation allows the use of CTD casts to determine that the methane-rich water mass is not laterally extensive across the pockmarks. The formation and linear arrangement of these pockmarks is likely related to linearly trending tension due to downslope creep at the shelf break. Their elongate shape may be related to the progressive merging of smaller, initially more circular pockmarks, consistent with apparently more vigorous venting at a smaller circular pockmark at the southern end of the elongated features.

\section{Acknowledgements}

We thank the captain and crew of the $R / V$ Cape Hatteras for their cooperation and Kevin Tomanka of Seafloor System, Inc. for his assistance in acquiring the multibeam bathymetric data. We thank Robert Houghton and Douglas Martinson for helpful insights into ocean mixing processes. This work was supported by NSF grants OCE0242426, OCE-0242804 and OCDE-0242449 and ONR grant N00014-02-1-0691. 


\section{Appendix. Response and Correction of the METS Sensor}

The METS sensor allows for near real time measurement of dissolved methane concentration from a moving platform. Most users report that the METS sensor reacts as expected with the ability to detect subtle changes in methane concentration [Bussel et al., 1999]. However, other studies [Lamontagne et al., 2001; Paull et al., 2002] show a time lag in its response and a delay in returning to "normal" values after reading high methane concentrations. Occasionally, concentrations measured by the METS sensor are significantly lower than those measured analytically. Conventional methods for determining dissolved methane concentration involve retrieving water samples from depth for later analysis [e.g. Clarke et al., 2000; Christodoulou et al., 2003]. The METS sensor employs a semiconductor whose resistance varies with the amount of methane present in the detection chamber. As methane molecules in the water diffuse across a silicon membrane into the chamber, they participate in an electron exchange with oxygen and modify the resistance across the semiconductor. The resulting change in the measured voltage is directly related to dissolved methane concentration (http://www.franaetch.com).

Visual inspection of the raw dissolved methane concentration, salinity and temperature time series data (Fig. 5) shows a correlation between the three constituents: elevated dissolved methane concentrations are observed in areas of decreased salinity and temperature. However, it appears the variations in dissolved methane concentration lag the corresponding salinity and temperature variations. When a square-shaped signal is observed in the salinity and temperature data, the dissolved methane concentration, recorded by the METS sensor, begins to increase at the start of the excursion and 
continues to increase until the end of the salinity/temperature anomaly, at which time it decays back to background levels. This is the expected response for diffusion across a membrane [Newman et al., 2005; Fukasawa et al, 2006]. The theoretical response of this process is that concentrations should increase as a function of $1-\exp (-\mathrm{t} / \tau)$, and decay as a function of $\exp (-\mathrm{t} / \tau)$, where $\tau$ is the time constant of the system. Fukasawa et al. [2006] give $\tau$ as the function $(\mathrm{VL}) /\left(\mathrm{RTAP}_{\mathrm{T}}\right)$, where $\mathrm{V}$ is the volume of the detector room, $\mathrm{L}$ is the membrane thickness, $\mathrm{R}$ is the gas constant, $\mathrm{T}$ is the water temperature, $\mathrm{A}$ is membrane permeation area and $\mathrm{P}_{\mathrm{T}}$ is boundary layer resistance. The response of the sensor can be expressed as the finite difference function

$$
y\left(t_{n}\right)=y\left(t_{n-1}\right)+\left[x\left(t_{n-1}\right)-y\left(t_{n-1}\right)\right]\left(1-e^{-\Delta t / \tau}\right),
$$

where $x(t)$ is the input function and $y(t)$ is the output. The actual signal can then be retrieved as

$$
x\left(t_{n}\right)=y\left(t_{n}\right)+\frac{y\left(t_{n+1}\right)-y\left(t_{n}\right)}{1-e^{-\Delta t / \tau}},
$$

All dive data were corrected using the above algorithm (Fig. 5) with the time constant for the system of approximately 11 minutes giving the best visual fit to the data. Although a low signal to noise ratio exists in the data recorded by the METS sensor, the data had to be low pass filtered prior to applying the correction because the algorithm amplifies high frequency noise. The noise was removed through empirical orthogonal function analysis. Each time series was analyzed separately. In all cases the first principle component was used as the filtered form of the data because it represented over $93 \%$, and in most cases, over $97 \%$ of the variance in the data.

Corrected methane concentrations are significantly larger than those measured in the hydrocast samples. This may be accounted for by the hydrocast samples being taken 
at a greater altitude above the seafloor than the AUV measurements. This is also consistent with the results of Chirstodoulou et al. [2003] where they observe an order of magnitude difference between near seafloor and upper water column measurements.

This instrumental response can also explain the differences in METS measured and analytically measured methane concentrations by Lamontagne et al. [2001]. Since the amount of time spent in some methane-rich areas is considerably shorter than the time constant of the instrument, the concentration measured by the instrument would not have had enough time to ramp up to the true value. 


\section{References}

Austin Jr., J.A., Christie-Blick, N., Malone, M.J,, et al., 1998. Proc. ODP, Init. Repts., 174A: College Station, TX (Ocean Drilling Program).

Berner, U., Poggenburg, J., Faber, E., Quadfasel, E., Frische, A. 2003. Methane in the ocean waters of the Bay of Bengal: its sources and exchange with the atmosphere. Deep-Sea Research II 50, 925-9250.

Blair, N.E., Leithold, E.L., Aller, R.C., 2004. From bedrock to burial: the evolution of particulate organic carbon across coupled watershed-continental margin systems. Marine Chemistry 92, 141-156.

Bohrmann, G., Heeschen, K., Jung, C., Weinrebe, W., Baranov, B., Cailleau, B., Heath, R., Hühnerbach, V., Hort, M., Masson, D., Trummer, I., 2002. Widespread fluid expulsion along the seafloor of the Costa Rica convergent margin. Terra Nova 14, 69-79.

Boles, J.R., Clark, J.F., Leifer, I., Washburn, L., 2001. Temporal variation in natural methane seep rate due to tides, Coal Oil Point area, California. J. Geophys. Res. 106 (C11), 27077-27086.

Borowski, W.S., Paull, C.K., Ussler, W., 1999. Global and local variations of interstitial sulfate gradients in deep-water, continental margin sediments: Sensitivity to underlying methane and gas hydrates. Marine Geology 159, 131-154.

Bumpus, D.F., 1973. A description of the circulation on the continental shelf of the east coast of the United States. Progress in Oceanography 6, 111-157.

Burrage, D.M., Garvine, R.W., 1982. Summertime Hydrography at the Shelfbreak Front in the Middle Atlantic Bight. J. Phys. Oceanogr. 18, 1309-1319.

Bussel, J., Klinkhammer, G., Collier, R., Linke, P., Appel, F., Heeschen, K., Suess, E., de Angelis, M.A., Masson, M., Marx, S., 1999. Applications of the METS Methane Sensor to the In-situ Detection of Methane Over a Range of Time Scales and 
Environments. presented at Fall AGU Meeting, San Fancisco, CA.

Çifçi, G., Dondurur, D., Ergün, M., 2003. Deep and shallow structures of large pockmarks in the Turkish shelf, Eastern Black Sea. Geo-Mar. Lett. 23, 311-322, doi:10.1007/s00367-003-0138-x.

Christodoulou, D., Papatheodorou, G., Ferentinos, G., Masson, M., 2003. Active seepage in two contrasting pockmark fields in the Patras and Corinth gulfs, Greece. GeoMar Lett. 23, 194-199, doi:10.1007/s00367-0063-0151-0.

Clarke, J.F., Washburn, L.,. Hornafus, J.S., Luyendyk, B.P., 2000. Dissolved hydrocarbon flux from natural marine seeps to the southern California Bight. J. Geophys. Res. 105, 11509-11522.

Claypool, G.E., Kaplan, I.R., 1974. The origin and distribution of methane in marine sediments, in Kaplan, I.R. (Ed.), Natural Gases in Marine Sediments. Plenum Press, New York, pp. 94-139.

Dimitrov, L. Woodside, J., 2002. Deep sea pockmark environments in the eastern Mediterranean. Marine Geology 195, 263-276.

Driscoll, N.W., Weissel, J.K., Goff, J.A., 2000. Potential for large-scale slope failure and tsunami generation along the U.S. mid-Atlantic coast. Geology 28, 407-410.

Eustice, R., Camilli, R., Singh, H., 2005. Towards Bathymetry-Optimized Doppler Renavigation for AUVs. Proc. IEEE/MTS OCEANS Conf. Exhib., Washington, DC, 1430-1436.

Flagg, C.N., Houghton, R.W., Pietrafesa, L.J., 1994. Summertime thermocline salinity maximum intrusions in the Mid-Atlantic Bight. Deep-Sea Res. II 41 (2/3), 325340.

Forrest, M.J., Ledesma-Vásquez, J. Ussler, W., Kulongoski, J.T., Hilton, D.R., Greene, H.G., 2005. Gas geochemistry of a shallow submarine hydrothermal vent associated with the El Requesón fault zone, Bahía Concepción, Baja California Sur, México. Chemical Geology 224, 82-95. 
Fukasawa, T., Hozumi, S., Morita, M., Oketani, T., Masson, M., 2006. Dissolved Methane Sensor for Methane Leakage Monitoring in Methane Hydrate Production. Proc. IEEE OCEANS Conf. Exhib., Boston, MA, 1-6.

Gordon, A.L. Aikmann III, F., 1981. Salinity maximum in the pycnocline of the Middle Atlantic Bight. Limnol. Oceanogr.,26 (1), 123-130.

Hedges, J.I., 1992. Global biogeochemical cycles: progress and problems. Marine Chemistry 39, 67-93.

Hill, J.C., Driscoll, N.W., Weissel, J.K., Goff, J.A., 2004. Large-scale elongate gas blowouts along the U.S. Atlantic margin. J. Geophys. Res. 109, B09101, doi:10.1029/2004JB002969.

Holbrook, S.W., Purdy, G.M., Sheridan, R.E., Glover III, L, Talwani, M., Ewing, J., Hutchinson, D., 1994. Seismic structure of the U.S. Mid-Atlantic continental margin. J. Geophys. Res. 99 (B9), 17871-17891.

Holmes, M.E., Sansone, F.J., Rustt, T.M., Popp, B.N., 2000. Methane production, consumption, and air-sea exchange in the open ocean: An evaluation based on carbon isotopic ratios. Global Biogeochem. Cycles 14 (1), 1-10.

Horita, J. and Berndt, M.E., 1999. Abiogenic Methane Formation and Isotopic Fractionation Under Hydrothermal Conditions. Science 285, 1055-1057.

Hovland, M., Judd, A.G., 1988. Seabed Pockmarks and Seepages, Impact on Geology, Biology and the Marine Environment. Graham and Trotman, London.

Hovland, M., Gardner, J.V., Judd, A.G., 2002. The significance of pockmarks to understanding fluid flow processes and geohazards. Geofluids 2, 127-136.

Ivanov, M., Westbrook, G.K., Blinova, V., Kozlova, E., Mazzini, A., Nouzé H., Minshull, T.A., 2007. First Sampling of Gas Hydrate From the Vøring Plateau. Eos Trans. AGU 88 (19), $209 \& 212$.

Judd, A.G., 2003. The global importance and context of methane escape from the seabed. Geo-Mar Lett. 23, 147-154, doi:10.1007/s00367-003-0136-z. 
Judd, A.G., Hovland, M. 2007. Seabed Fluid Flow: The Impact on Geology, Biology and the Marine Environment. Cambridge University Press, New York. 475 pp.

Judd, A.G., Hovland, M., Dimitrov, L.I., Carcía Gil, S., Jukes, V., 2002. The geological methane budget at Continental Margins and its influence on climate change. Geofluids 2, 109-126.

Kelley, J.T., Dickson, S.M., Belknap, D.F., Barnhardt, W.A., Henderson, M., 1994. Giant sea-bed pockmarks: Evidence for gas escape from Belfast Bay, Maine. Geology $22,59-62$.

King, L.H., McLean, B., 1970. Pockmarks on the Scotian Shelf. GSA Bulletin 81, 31413148.

Lamontagne, R.A., Rose-Pehrsson, S.L., Grabowski, K.E., Knies, D.L., 2001. Response of METS Sensor to Methane Concentrations found on the Texas-Louisiana Shelf in the Gulf of Mexico. Naval Research Laboratory Memorandum Report NRLMR-6110-01-8584, Washington, DC, 15 October, 13 pp.

Lonke, L, Mascle, J., Fanil Scientific Parties, 2004. Mud volcanoes, gas chimneys, pockmarks and mounds in the Nile deep-sea fan (Eastern Mediterranean): geophysical evidences. Marine and Petroleum Geology 21, 669-689.

Mikolaj, P.G., Ampaya, J.P.,1973. Tidal effects on the activity of natural submarine oil seeps. Marine Technology Society Journal 7, 25-28.

Newman, K., Cormier, M., Driscoll, N., Hill, J., Kastner, M., Singh, H., Weissel, J., 2005. Geophysical and Geochemical Evidence for Methane Venting at Large Gas Blowouts Along the US Mid-Atlantic Shelf Edge. Eos Trans. AGU 86 (52), Fall Meet. Suppl., Abstract OS32A-05.

Orange, D.L.,Saffer, D., Maher, N., 1997. Tidally Mediated Fluid Expulsion at a Cold Seep. Eos Trans. AGU 78 (52), Fall Meet. Suppl. Abstract T31E-11.

Paull, C.K., Ussler, W., Maher, N., Greene, H.G., Rehder, G., Lorenson, T., Lee, H., 2002. Pockmarks off Big Sur, California. Marine Geology 181 (4), 323-355. 
Popp, B.N., Sansone, F.J., Rust, T.M., Merritt, D.A., 1995. Determination of concentration and carbon isotopic composition of dissolved methane in sediments and nearshore waters. Anal. Chem. 67, 405-411.

Raymond, P.A., Bauer, J.E., 2001. Riverine export of aged terrestrial organic matter to the North Atlantic Ocean. Nature 409, 497-500.

Reeburgh, W.S., 2007. Oceanic methane biogeochemistry. Chem. Rev. 107, 486-513. Sansone, F.J., Popp, B.N., Gasc, A., Graham, A.W.,. Rust, T.M., 2001. Highly elevated methane in the eastern tropical North Pacific and associated isotopically enriched fluxes to the atmosphere. Geophys. Res. Lett. 28 (24), 4567-4570.

Sibuet, M., Olu, K., 1998. Biogeography, biodiversity and fluid dependence of deep-sea cold-seep communities at active and passive margins. Deep-Sea Research II 45, $517-567$.

Sills, G.C., Wheeler, S.J., 1992. The significance of gas for offshore operations. Continental Shelf Research 12 (10), 1239-1250.

Singh, H., Armstrong, R., Gilbes, F., Eustice, R., Roman, C., Pizarro, O., Torres, J., 2004a. Imaging Coral I: Imaging Coral Habitats with The SeaBED AUV. The Journal for Subsurface Sensing Technologies and Applications 5 (1), 498-514.

Singh, H., Can, A., Eustice, R., Lerner, S., McPhee, N., Pizzaro, O., Roman, C., 2004b SeaBED AUV Provides New Platform for High Resolution Imaging. Eos Trans., AGU 85 (31), 289, 294-295.

Torres, M.E., McManus, J., Hammond, D., Angelis, M., Heeschen, K.U., Colbert, S.L., Tryon, M.D., Brown, K.M., Suess, E., 2002. Fluid and chemical fluxes in and out of sediments hosting methane hydrate deposits on Hydrate Ridge, OR, I. Hydrological provinces. Earth and Planetary Sciences Letters 201, 525-540.

Ussler III, W., Paull, C.K., Boucher, J., Friederich, G.E., Thomas, D.J., 2003. Submarine pockmarks: a case study from Belfast Bay, Maine. Marine Geology 202 (3-4), 175-192. 
Whitcomb, L., Yoerger, D., Singh, H., Howland, J., 2000. Advances in Underwater Robot Vehicles for Deep Ocean Exploration: Navigation, Control and Survey Operations. Robotics Research - The Ninth International Symposium. SpringerVerlag Publications, London, pp. 439-448.

Whiticar, M.J., Faber, E., Schoell, M., 1986. Biogenic methane formation in marine and freshwater environments: $\mathrm{CO}_{2}$ reduction vs. acetate fermentation - Isotope evidence. Geochim. Cosmochim. Acta 50, 693-709. 
Table 1. Pore fluid geochemistry data

\begin{tabular}{ccc}
\hline $\begin{array}{c}\text { Core } \\
\text { Number }\end{array}$ & Depth to SMI (cmbsf) & Min. . $^{13} \mathrm{C}$ DIC (\%) \\
\hline $10 \mathrm{P}$ & SMI not reached & -34.4 \\
$23 \mathrm{P}$ & $150-159$ & -32.1 \\
$25 \mathrm{P}$ & $125-143$ & -30.9 \\
$30 \mathrm{P}$ & $50-65$ & \\
$31 \mathrm{P}$ & $125-147$ & \\
$34 \mathrm{P}$ & $49-65$ & \\
\hline
\end{tabular}




\section{Figure Captions}

Figure 1. Bathymetric map of the survey area produced with the ELAC-1180 multibeam sonar during the July 2004 survey. Core locations are plotted as circles, black for cores squeezed for pore water geochemistry and red for those saved for stratigraphy. Green stars show the locations of hydrocast sampling. Cores 10P, 23P, 25P, 30P and 31P and hydrocasts 5 and 7 are identified. Red boxes show the areas displayed in Figure 7 . Inset is an overview map of the area with the red star showing the location of the survey area. Visible coastlines in the inset map are, from north to south, the southern tip of New Jersey, the Delmarva Peninsula, and the barrier islands offshore North Carolina.

Figure 2. Chirp seismic profile across a shelf edge pockmark, modified from Hill et al. [2004]. Gas-charged sediments are visible along the western wall of the pockmark, extending westward under the shelf. Gas-charged sediments are identified as a high amplitude reflector that obscures underlying reflectors.

Figure 3. The SeaBED AUV. The protective, outer coverings have been removed to expose the instrumentation.

Figure 4. Effect of near bottom currents measured by the ship's ADCP in the survey area. The bottom three bins (each bin is $8 \mathrm{~m}$ ) above the seafloor have been averaged. The plot shows total displacement of a parcel of water over a 12 hour period with ticks every hour. A southerly current of $0.2 \mathrm{~km} / \mathrm{h}$ dominates, which is consistent with the 
previously documented shelf-edge current [e.g. Bumpus, 1973]. Tidal effects are expressed as east/west excursions.

Figure 5. Near-bottom water properties collected by the SeaBED AUV during dive 16 (located in Figure 7a). The black line is the raw dissolved methane data generated by the METS sensor. The red line is the data filtered using the first principle component from empirical orthogonal function analysis (see Appendix). The green line is the corrected dissolved methane. The blue line is salinity, measured by the AUV mounted SeaBird CTD. Temperature data are not plotted, but they follow a similar pattern as the salinity data, as illustrated Figure 6.

Figure 6. Along track data from dive 16 (located in Figure 7a) displaying the categorization of the methane anomaly. White areas are background concentration, darkly shaded are high methane concentration and lightly shaded are intermediate methane concentration. A correlation is typically observed in all dives between salinity, temperature and dissolved methane concentration.

Figure 7. Bathymetry maps of the pockmarks showing the spatial distribution of the methane anomaly. Black is background methane concentration, red is high methane concentration and green is intermediate methane concentration (see text for details). AUV dive numbers are given at the beginning of the dive track. 
Figure 8. Top panel: CTD and dissolved methane concentration profile from hydrocast 5, which sampled the eastern wall of a large pockmark (located in Fig. 1). Salinity is plotted in black, temperature in gray and the laboratory measured dissolved methane concentration as points. Some correlation between dissolved methane concentration, salinity and temperature is seen in the lower part of the profile, but it begins to break down at depths shallower than the peak methane concentration. A step is visible in salinity and temperature at $110 \mathrm{~m}$, the depth at which methane begins to increase in the profile. Bottom panel: CTD profile from AUV dive 9 ascent, which sampled the center of the same pockmark (Fig. 7b). No steps, except for noisy excursions, are visible in this profile, suggesting that the methane-rich water mass that is slightly colder and fresher than the bottom water is not present at this location.

Figure 9. Sulfate and DIC $\delta^{13} \mathrm{C}$ profile for core 23P. Sulfate is plotted in black, DIC $\delta^{13} \mathrm{C}$ in gray. Sulfate concentration is nearly zero at $150-159 \mathrm{~cm}$ below seafloor, marking the depth of the sulfate-methane interface.

Figure 10. Proposed methane venting scenario. Left panel data are from hydrocast 7 and plotting conventions are the same as in Figure 8. The right panel shows a representative chirp profile across one of the pockmarks [Hill et al. 2004]. White arrows denote the location of methane venting. The shaded areas indicate where methane-rich water is found, suggesting spreading due to diffusion and advection due to currents. The bold line simulates the AUV track across the pockmark and the dashed line simulates the location of the hydrocast data presented in the left panel. 


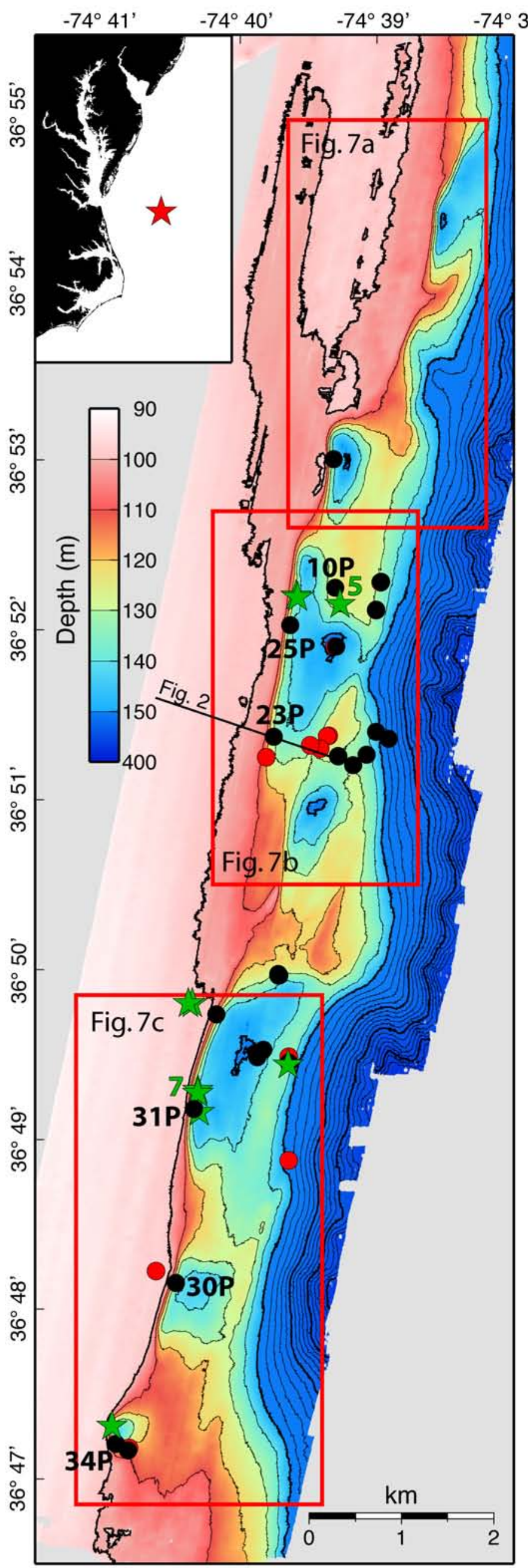

Figure 1 


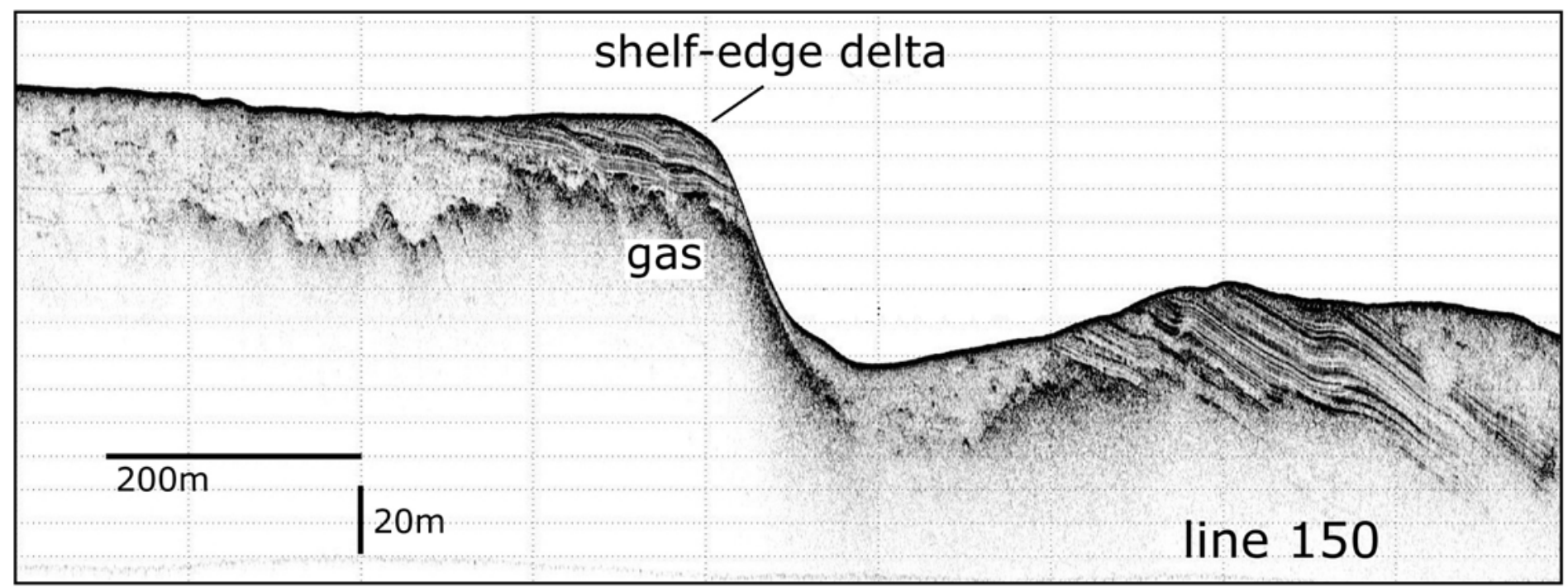

Figure 2
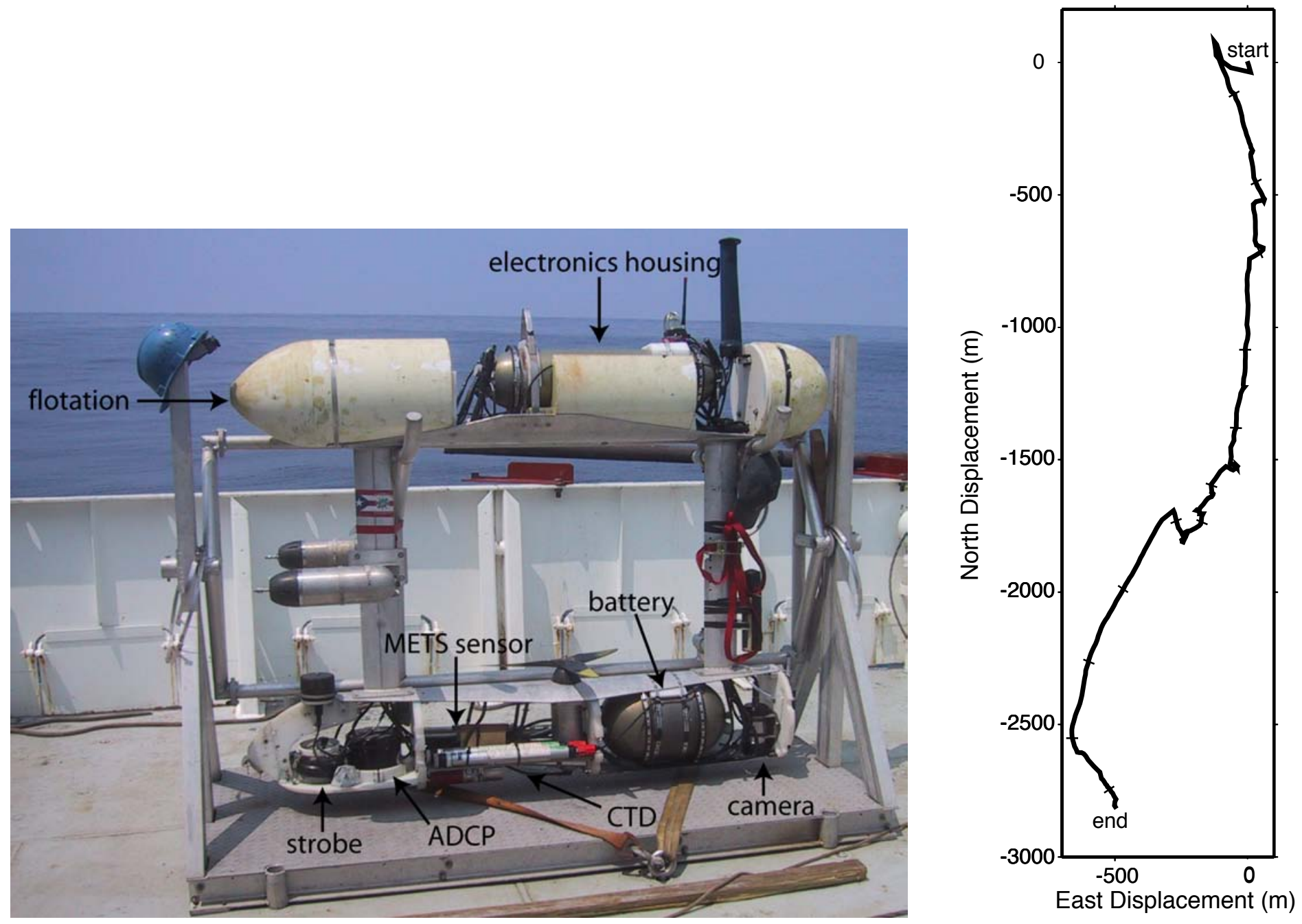

Figure 3

Figure 4 


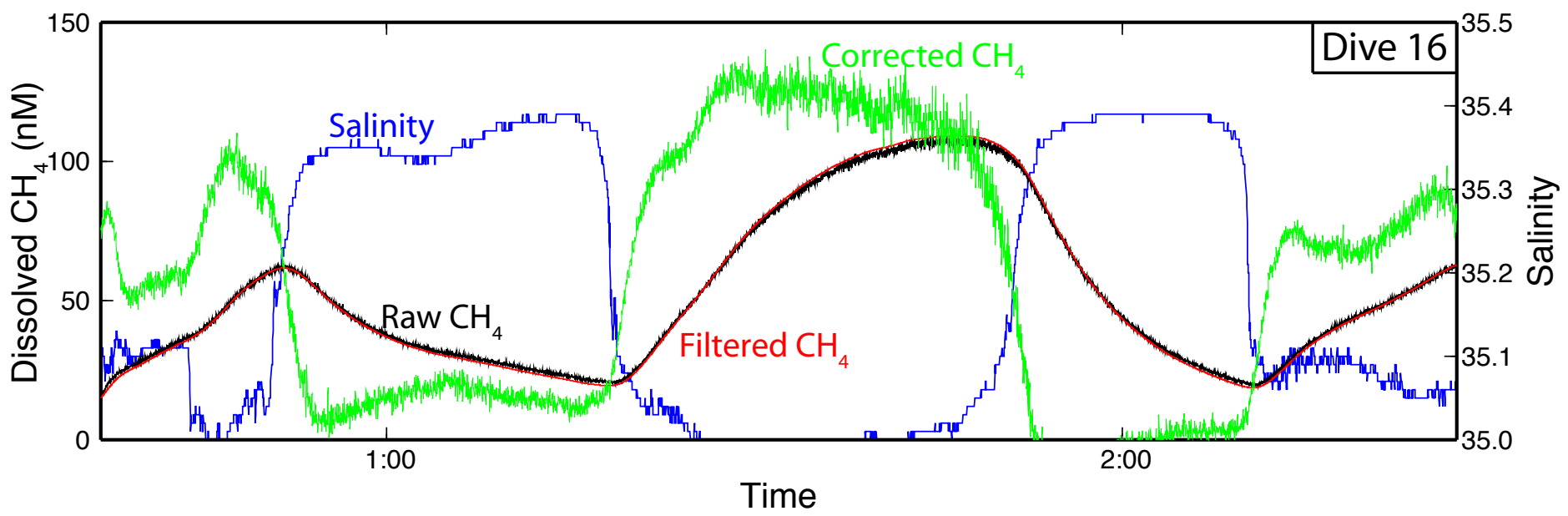

Figure 5

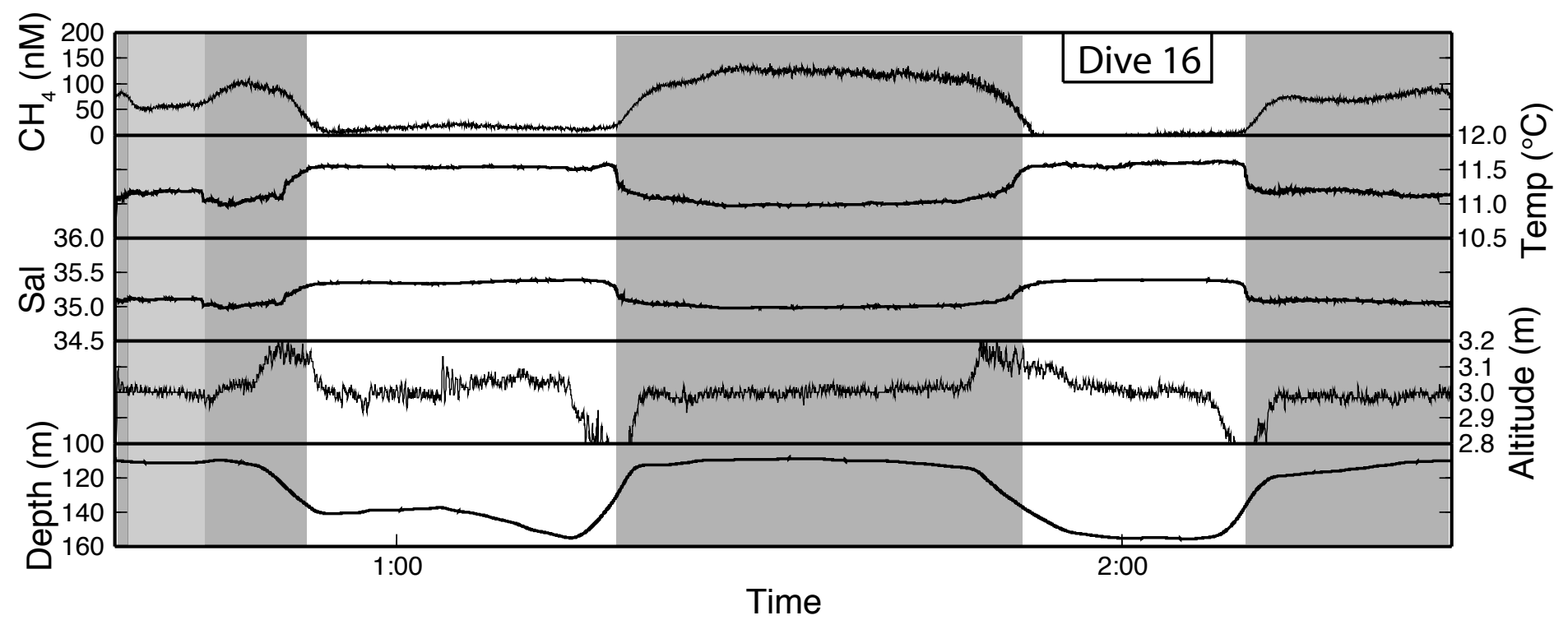

Figure 6 

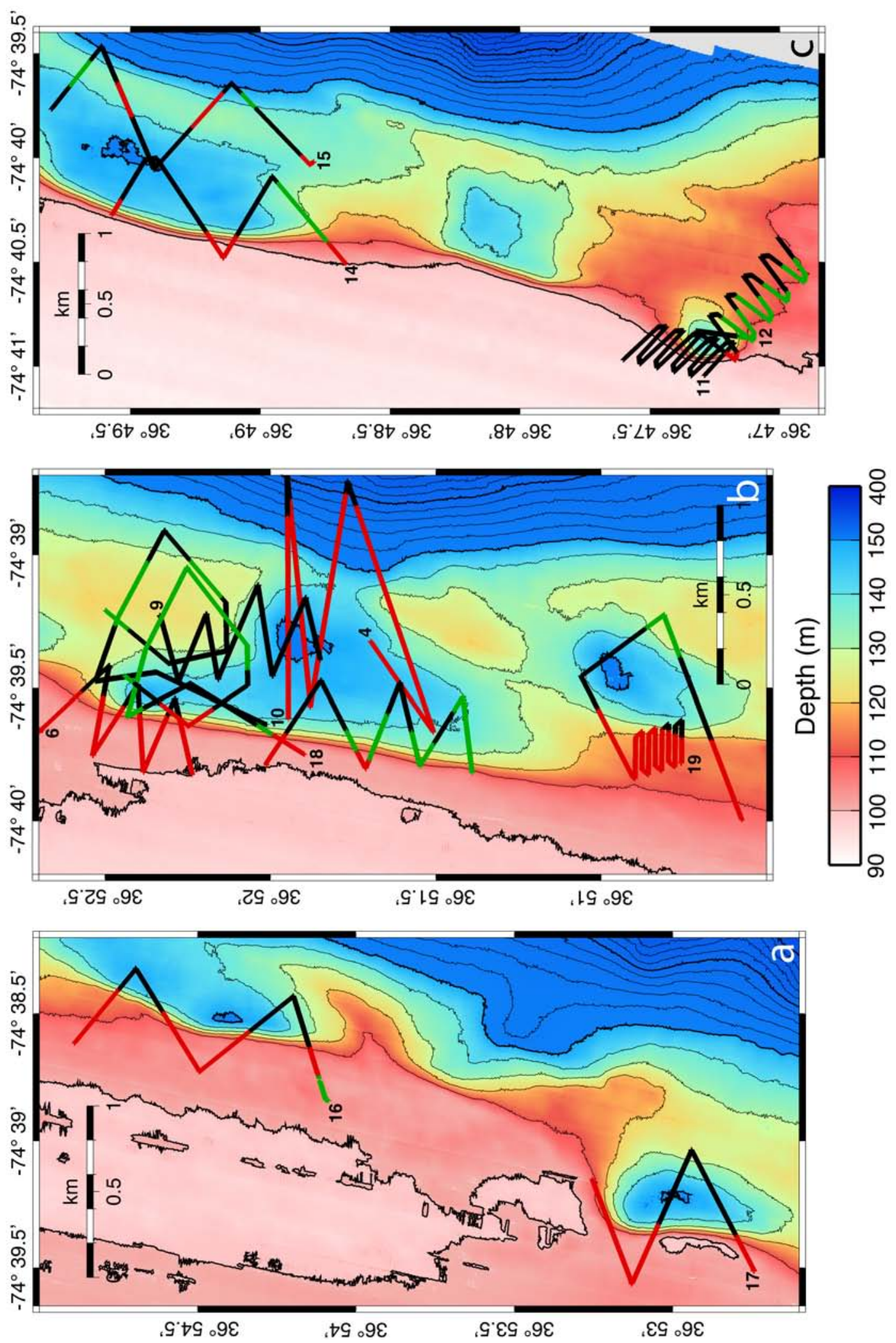

Figure 7 

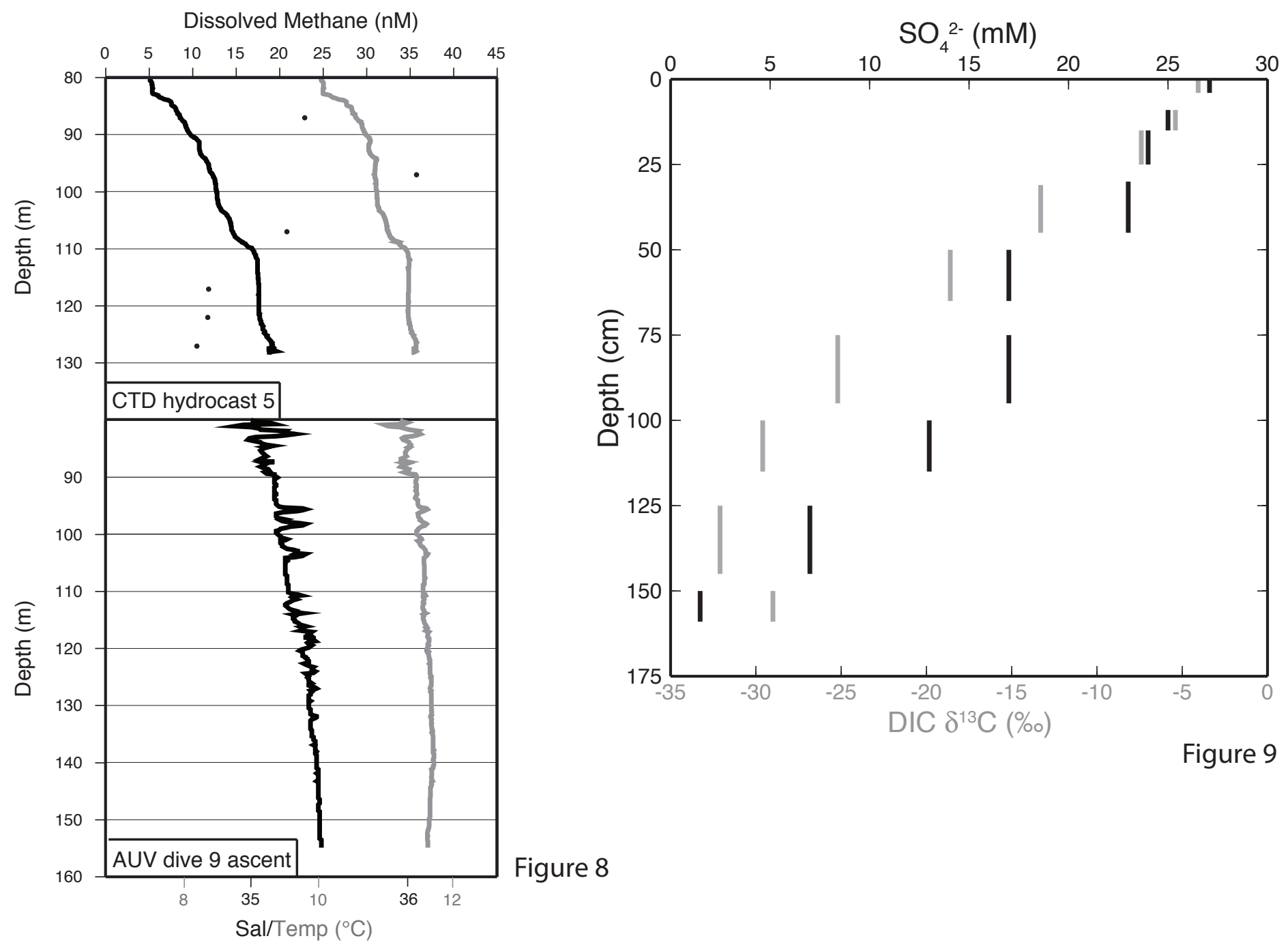

Figure 9

Figure 8

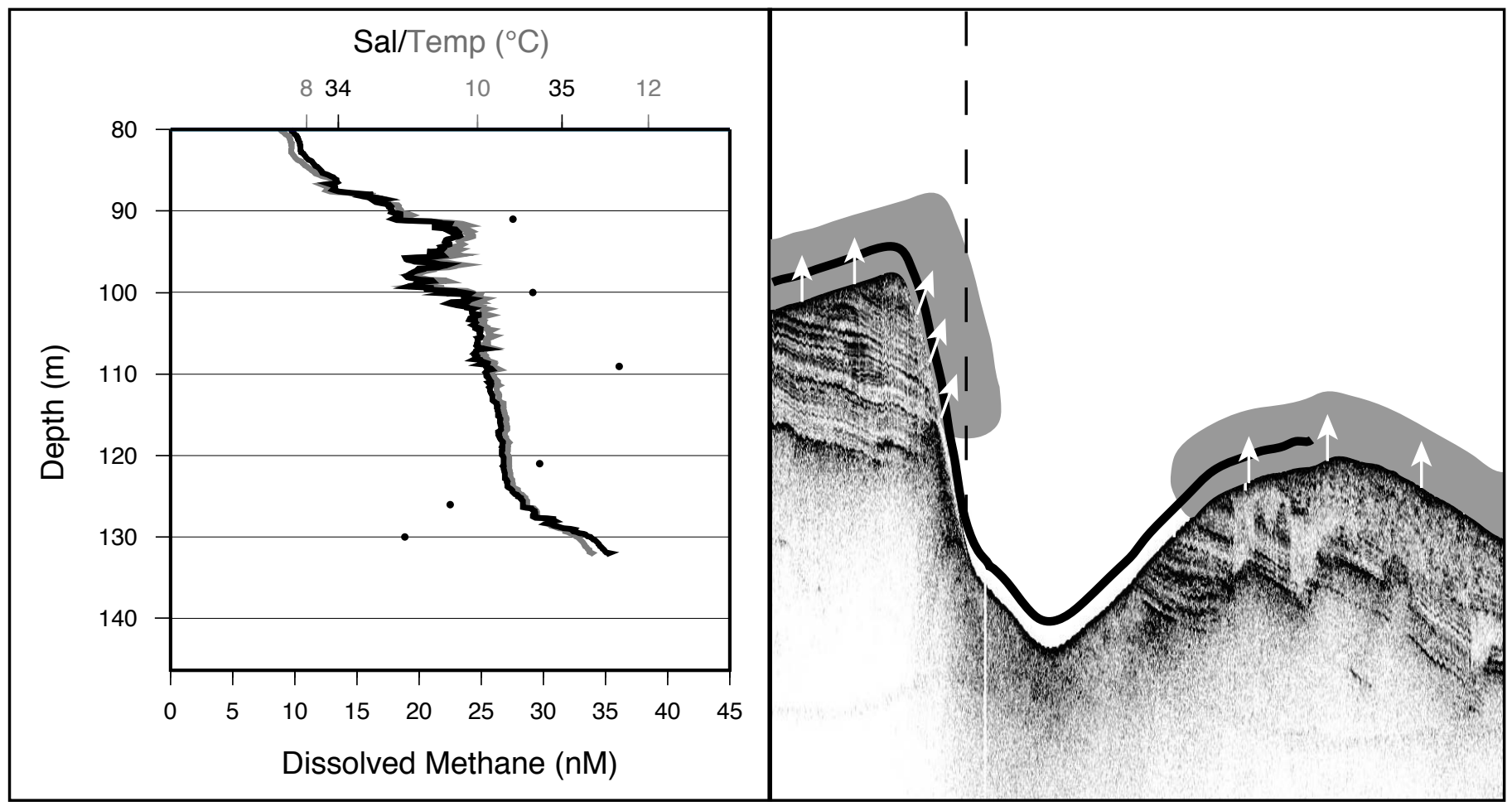

Figure 10 
Supplementary Table 1. Hydrocast Data

\begin{tabular}{|c|c|c|c|c|c|}
\hline \multirow{2}{*}{ CTD \# } & \multicolumn{2}{|c|}{ CTD Location } & \multirow{2}{*}{ Depth (mbsl) } & \multirow{2}{*}{ Methane $(\mathrm{nM})$} & \multirow{2}{*}{$\mathrm{CH}_{4} \delta^{13} \mathrm{C}(\%)$} \\
\hline & Lat. $\left({ }^{\circ} \mathrm{N}\right)$ & Lon. $\left({ }^{\circ} \mathrm{W}\right)$ & & & \\
\hline \multirow{6}{*}{$\mathrm{CH} 1$} & \multirow{6}{*}{36.8240} & \multirow{6}{*}{74.6608} & 85 & 36.665 & \\
\hline & & & 100 & & \\
\hline & & & 110 & 13.217 & \\
\hline & & & 120 & 14.176 & \\
\hline & & & 130 & 5.637 & \\
\hline & & & 136 & 5.053 & \\
\hline \multirow{6}{*}{$\mathrm{CH} I \mathrm{I}$} & \multirow{6}{*}{36.8193} & \multirow{6}{*}{74.6717} & 87 & 22.883 & \\
\hline & & & 97 & 35.751 & \\
\hline & & & 107 & 20.831 & \\
\hline & & & 117 & 11.864 & \\
\hline & & & 122 & 11.728 & \\
\hline & & & 127 & 10.485 & \\
\hline \multirow{6}{*}{$\mathrm{CH}$ III } & \multirow{6}{*}{36.8197} & \multirow{6}{*}{74.6725} & 97 & 20.487 & \\
\hline & & & 107 & 22.350 & \\
\hline & & & 117 & 25.465 & \\
\hline & & & 122 & 29.186 & \\
\hline & & & 127 & & \\
\hline & & & 132 & 21.228 & \\
\hline \multirow{6}{*}{$\mathrm{CH}$ IV } & \multirow{6}{*}{36.8197} & \multirow{6}{*}{74.6730} & 91 & 27.540 & -64.31 \\
\hline & & & 100 & 29.134 & -65.00 \\
\hline & & & 109 & 36.089 & -61.99 \\
\hline & & & 121 & 29.721 & -62.88 \\
\hline & & & 126 & 22.515 & -63.72 \\
\hline & & & 130 & 18.840 & -63.19 \\
\hline \multirow{6}{*}{$\mathrm{CH} \mathrm{V}$} & \multirow{6}{*}{36.8692} & \multirow{6}{*}{74.6545} & 105 & 22.440 & \\
\hline & & & 115 & 23.713 & \\
\hline & & & 120 & 21.122 & \\
\hline & & & 125 & 25.931 & \\
\hline & & & 130 & 30.945 & \\
\hline & & & 140 & 15.047 & \\
\hline \multirow{12}{*}{$\mathrm{CH} \mathrm{VI}$} & & & 16 & 5.227 & -45.58 \\
\hline & & & 30 & 10.375 & -49.42 \\
\hline & & & 50 & 2.544 & \\
\hline & & & 59 & 23.724 & -65.27 \\
\hline & & & 68 & 42.743 & -63.29 \\
\hline & 36.8692 & 74.6598 & 88 & 26.604 & -62.60 \\
\hline & 50.009L & 14.0590 & 98 & 23.957 & -61.06 \\
\hline & & & 106 & 24.628 & -63.24 \\
\hline & & & 115 & 33.248 & -62.23 \\
\hline & & & 122 & 33.400 & -61.04 \\
\hline & & & 130 & 21.390 & -60.84 \\
\hline & & & 139 & 22.418 & -59.09 \\
\hline & & & 99 & 27.796 & \\
\hline & & & 109 & 24.925 & \\
\hline $\mathrm{CH}$ VII & 36.8215 & 74.6718 & 119 & 21.593 & \\
\hline Uit vil & & & 124 & 29.695 & \\
\hline & & & 129 & 24.541 & \\
\hline & & & 134 & 24.429 & \\
\hline
\end{tabular}


Supplementary Table 2. Pore fluid analyses

\begin{tabular}{|c|c|c|c|c|c|c|c|c|}
\hline \multirow{2}{*}{ Core } & \multicolumn{2}{|c|}{ Core Location } & \multirow{2}{*}{$\begin{array}{l}\text { Depth Interval } \\
\quad(\mathrm{cmbsf})\end{array}$} & \multirow{2}{*}{$\begin{array}{l}\mathrm{SO}_{4}{ }^{2-} \\
(\mathrm{mM})\end{array}$} & \multirow{2}{*}{$\begin{array}{c}\text { DIC } \delta^{13} C \\
(\% \circ)\end{array}$} & \multirow{2}{*}{$\begin{array}{l}\text { Alkalinity } \\
(\mathrm{mM})\end{array}$} & \multirow{2}{*}{$\begin{array}{c}\mathrm{Ca} \\
(\mathrm{mM})\end{array}$} & \multirow{2}{*}{$\begin{array}{c}\mathrm{Mg} \\
(\mathrm{mM})\end{array}$} \\
\hline & Lat. $\left({ }^{\circ} \mathrm{N}\right)$ & Lon. $\left({ }^{\circ} \mathrm{W}\right)$ & & & & & & \\
\hline \multirow{9}{*}{$\mathrm{CH} 10 \mathrm{P}$} & \multirow{9}{*}{36.87078} & \multirow{9}{*}{74.65507} & $0-4$ & 30.06 & -3.8 & 2.17 & 10.64 & 52.31 \\
\hline & & & $6-9$ & 30.64 & & 2.33 & 11.02 & 53.63 \\
\hline & & & $9-15$ & 29.97 & & 2.55 & 10.82 & 53.13 \\
\hline & & & $15-25$ & 28.87 & & 2.92 & 10.42 & 53.47 \\
\hline & & & $30-40$ & 27.50 & -10.1 & 3.88 & 10.09 & 52.86 \\
\hline & & & $45-61$ & 26.63 & -19.9 & 5.78 & 9.11 & 49.87 \\
\hline & & & 69-85 & 21.38 & -25.3 & 7.15 & 7.99 & 46.20 \\
\hline & & & $100-115$ & 8.13 & -30.5 & 10.37 & 6.25 & 29.98 \\
\hline & & & $115-138$ & 7.38 & -34.3 & 10.41 & 5.78 & 38.25 \\
\hline \multirow{10}{*}{$\mathrm{CH} 23 \mathrm{P}$} & \multirow{10}{*}{36.85615} & \multirow{10}{*}{74.66258} & $0-4$ & 26.50 & -3.4 & 2.65 & 10.91 & 52.94 \\
\hline & & & $4-9$ & & & 2.68 & 10.47 & 51.43 \\
\hline & & & $9-15$ & 25.00 & -5.4 & 2.66 & 10.57 & 52.12 \\
\hline & & & $15-25$ & 24.00 & -7.4 & 3.01 & 10.48 & 52.95 \\
\hline & & & $31-45$ & 23.00 & -13.3 & 4.28 & 9.95 & 52.00 \\
\hline & & & $50-65$ & 17.00 & -18.6 & 5.46 & 9.34 & 50.61 \\
\hline & & & $75-95$ & 17.00 & -25.2 & 8.13 & 8.07 & 46.91 \\
\hline & & & $100-115$ & 13.85 & -29.6 & 11.13 & 7.06 & 43.08 \\
\hline & & & $125-145$ & 6.94 & -32.1 & 14.31 & 5.96 & 38.33 \\
\hline & & & $150-159$ & 1.52 & -29.0 & 13.70 & 4.54 & 32.34 \\
\hline \multirow{9}{*}{$\mathrm{CH} 25 \mathrm{P}$} & \multirow{9}{*}{36.86713} & \multirow{9}{*}{74.66055} & $0-2$ & 29.05 & & 2.70 & 10.50 & 51.75 \\
\hline & & & 4-9 & 29.00 & & 2.84 & 10.64 & 51.87 \\
\hline & & & $9-15$ & 28.00 & & 3.58 & 10.38 & 51.30 \\
\hline & & & $15-25$ & 22.57 & & 6.51 & 9.22 & 47.97 \\
\hline & & & $30-45$ & 12.27 & & 11.09 & 7.02 & 40.03 \\
\hline & & & $50-65$ & 4.80 & & 14.52 & 5.55 & 34.90 \\
\hline & & & $75-87$ & 3.21 & & 12.25 & 4.49 & 31.82 \\
\hline & & & $100-115$ & 2.50 & & 11.45 & 4.11 & 30.12 \\
\hline & & & $125-143$ & 1.98 & & 10.68 & 3.88 & 29.08 \\
\hline \multirow{6}{*}{$\mathrm{CH} 30 \mathrm{P}$} & & & $0-4$ & 29.01 & & 2.43 & 10.88 & 52.75 \\
\hline & & & $4-9$ & 28.98 & & 3.43 & 10.68 & 53.85 \\
\hline & & & $9-15$ & 27.46 & & 3.74 & 10.26 & 52.35 \\
\hline & 36.80255 & 74.66957 & $15-25$ & 22.97 & & 6.20 & 9.35 & 49.38 \\
\hline & & & $30-45$ & 12.07 & & 12.27 & 7.22 & 41.05 \\
\hline & & & $50-65$ & 1.64 & & 16.00 & 5.16 & 32.99 \\
\hline & & & $0-4$ & 28.99 & & 2.63 & 10.65 & 53.29 \\
\hline & & & $4-9$ & 29.00 & & 2.61 & 10.69 & 53.30 \\
\hline & & & $9-19$ & 27.43 & & 2.97 & 10.10 & 51.35 \\
\hline & & & $19-25$ & 26.67 & & 3.54 & 10.02 & 51.38 \\
\hline & & & $30-45$ & 16.83 & & 8.21 & 7.81 & 43.31 \\
\hline СН31P & 36.81965 & $14.6 / 233$ & $49-65$ & 10.51 & & 9.39 & 5.91 & 36.70 \\
\hline & & & $75-90$ & 5.68 & & 10.32 & 4.67 & 32.61 \\
\hline & & & $99-115$ & 3.04 & & 10.27 & 3.99 & 29.84 \\
\hline & & & $125-147$ & 1.10 & & 11.02 & 3.74 & 29.21 \\
\hline & & & $160-175$ & 0.48 & & 10.77 & 3.66 & 28.81 \\
\hline & & & $0-4$ & 28.54 & & 2.69 & 10.62 & 52.96 \\
\hline & & & $4-9$ & 28.31 & & 2.90 & 10.49 & 52.78 \\
\hline & & & $9-15$ & 26.17 & & 3.89 & 10.55 & 51.35 \\
\hline & & & $15-25$ & 21.24 & & 6.00 & 8.81 & 47.42 \\
\hline CH34P & $36.186 / 5$ & 14.68183 & $30-40$ & 3.52 & & 10.53 & 4.56 & 31.91 \\
\hline & & & $49-65$ & 0.13 & & 10.69 & 3.86 & 29.17 \\
\hline & & & $75-89$ & 0.18 & & 10.49 & 3.69 & 28.79 \\
\hline & & & $100-115$ & 0.43 & & 9.02 & 3.69 & 28.51 \\
\hline
\end{tabular}

